\title{
塗裝面に対する熔接施エについで
}

\author{
吉田俊夫** 松永和介** 金谷交善** 小野靖彦**
}

\section{Weldability of Steel Coated with Various Paints*}

By T. Yoshida,** W. Matsunaga,** F. Kanatani** and Y. Ono**

\begin{abstract}
In order to investigate the weldability of mild steel coated with various paints, we made some exper. iments and obtained the following summaries ;

1. In manual welding (low hydrogen type and ilmenite type) and semi-automatic welding (high iron powder type), several kinds of paints, including wash primer, iron oxide, zinc chromate and new paint (oleoresinous) whose film thickness not exceeding 2 mils, had little effect on the ease of arc start, arc stability, bead appearance and on the result of the radiographic inspection.

2. Every paint film having thickness of not less than 5 mils had significant effect on the weldability of mild steel.

3. Paint films were very harmful in submerged arc welding, irrespective of kinds of paints or film thickness.

4. According to the Lehigh restraint tests, a 2-mil coat of wash primer and new paint (oleoresinous) had no effect but iron oxide and zinc chromate caused a slight rise of crack sensitivity.

5. 2-mil coat of four kinds of above-mentioned paints has no detrimental effect on V-notch Charpy im. pact values of deposited metals, though wash primer lowered them a little.

6 . Viewing from what we stated above, we may say that wash primer, iron oxide, zinc chromate and new paint (oleoresinous) films, not exceeding a film thickness of 2 mils, have no detrimental effect on the weldability of mild steel in manual welding and semi-automatic welding.
\end{abstract}

\section{1 緒言}

船体を構成する鋼材を有機泾膜によって防食する場合乼 装前処理の中最も重姴で塗装初果を非常に大きく左右する 要素は Descaling であるが，このいわゆる「銷落し」は同 時得も工数を要するばかりでなくそのGradeの指定扔よ び指示された Gradeの維持のコントロールがむずかしい。 更腐食德境のきびしい個所以ミルスケールを残して塗装 した場合，湤しい電気化学的腐食を誘発する危險性むまた 知られる通りである。

我々はこのDescaling をショット・ブラスターにより機 栈的沟一飞確実に施工した後直ちに Primer を叙装する ととにより，次のような利益を得ることができる.

(1) 塗装前処理の完全化.

（口） Storage たは Handling, Construction 中の鋼材の 防食

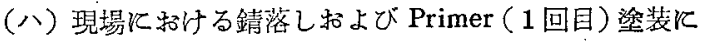
要する外業工数の省略（但し部分的な補修は必要）

（二) Priming Coat の Holiday Work の解消飞よる防食 の完全化（特比ーム，スチフナー，フレーム等の背

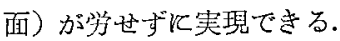

* 原稿受付 昭和 33 年 7 月 31 日（昭和 33 年度熔接学会秋

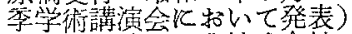

** 正員, M㥓重工業株式会社 Member, Kawasaki Dockyard Co., Ltd.
この場合必然的に塗装面に対する撘接施工といった閭題 が生じて来る。

塗装面に対する熔接能工の可否飞関する研究はすでに各 方面炕怙いて行われ，厚さ $3 \mathrm{mil}(0.08 \mathrm{~mm})$ 程度のある種

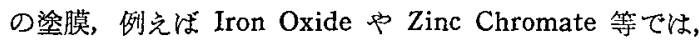
接手の熔接性になんら悪影響を挌よぼさないとの結諭も出 されている.

筆者らはこれらの研究を参考とし，充分な防錆能力を持 ちしかも橴接性を損わない慗装方法を調查するととを目 的として次の上うな実験的研究を行った。すなわち先ず8

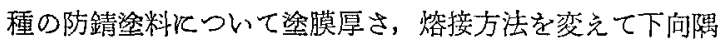
肉熔接を行い，作業性，ビード外観，気泡発生の有無を調 查した. 次にこの調查により比較的優れた結果分得られた 4 種の塗料沉ついてさらにリー八イ式拘束龟裂性試験特よ び熔着金属の標準 Vシャルピー衛馨試験を行い，叙料が癿 裂性と熔接接手性能に和よに゙す影響も合わせて調查した。 な招静的機械強度には熔接部気泡その他の欠陷が存在し ない限り塗料の影響が晲われないととが多くの実験で明ら かとなっているので静的機械試験临略した。

\section{2 工 作 性 試 験}

試験材は，ショットブラストをかけ篗装を行った後， Fig. 1 亿示す形状に組立て仮付を行った. 使用した塗料 
Table 1 Chemical Composition of Paints Tested

\begin{tabular}{|c|c|c|c|c|c|c|c|c|c|c|c|c|c|c|c|c|}
\hline \multirow{2}{*}{ Paint } & \multicolumn{16}{|c|}{ Chemical composition (\%) } \\
\hline & $\mathrm{C}$ & $\mathrm{Al}$ & $\mathrm{MgO}$ & $\mathrm{CaO}$ & $\mathrm{SiO}_{2}$ & $\mathrm{TiO}_{2}$ & $\mathrm{ZnO}$ & $\mathrm{K}_{2} \mathrm{O}$ & $\mathrm{H}_{3} \mathrm{PO}_{4}$ & $\mathrm{CaCO}_{3}$ & $\left|\mathrm{Al}_{2} \mathrm{O}_{3}\right|$ & $\mathrm{Fe}_{2} \mathrm{O}_{3}$ & $\mathrm{ZnCrO}_{4}$ & $\mathrm{PbCrO}_{4}$ & $\left|\mathrm{~Pb}_{3} \mathrm{O}_{4}\right|$ & Vehicle \\
\hline Wash primer & 0.5 & - & 1.9 & - & 2.4 & - & - & - & 21.0 & - & - & - & 8.1 & 32.1 & - & 34.0 \\
\hline Iron oxide & - & - & - & - & - & - & 5.8 & - & - & 49.2 & - & 11.5 & - & - & - & 33.5 \\
\hline $\begin{array}{l}\text { Aluminum } \\
\text { (Oleoresinous) }\end{array}$ & - & 28.3 & - & - & - & - & - & - & - & - & - & - & - & - & - & 71.7 \\
\hline $\begin{array}{l}\text { Aluminum } \\
\text { (Vinyl) }\end{array}$ & - & 42.7 & - & - & - & - & - & - & - & - & - & - & - & - & - & 57.3 \\
\hline $\begin{array}{l}\text { Zinc chromate } \\
\text { (Oleoresinous) }\end{array}$ & - & - & 4.0 & 1.1 & 6.1 & 10.2 & 13.1 & - & - & - & - & 3.5 & 36.9 & - & - & 26.1 \\
\hline Red lead & - & - & 9.3 & - & 19.8 & - & - & - & - & - & 5.3 & 1.7 & 5.7 & 6.6 & 26.3 & 25.3 \\
\hline $\begin{array}{l}\text { New paint } \\
\text { (Oleoresinous) }\end{array}$ & - & - & 2.4 & 0.3 & 5.1 & 44.3 & - & 0.6 & - & - & 1.6 & 19.5 & - & - & - & - \\
\hline $\begin{array}{l}\text { New paint } \\
\text { (Vinyl) }\end{array}$ & 6.8 & - & 1.4 & 0.3 & 3.4 & 27.1 & - & 0.6 & - & - & 1.4 & - & - & - & - & 59.3 \\
\hline
\end{tabular}

Table 2 Welding Processes

\begin{tabular}{|c|c|c|c|c|c|c|c|c|}
\hline \multirow{2}{*}{$\begin{array}{l}\text { Welding } \\
\text { process }\end{array}$} & \multicolumn{2}{|c|}{ Rod } & \multirow{2}{*}{$\begin{array}{l}\text { Flux } \\
\text { name }\end{array}$} & \multicolumn{2}{|c|}{ Classification } & \multicolumn{3}{|c|}{ Welding condition } \\
\hline & Name & Dia. & & JIS & AWS & Current & Voltage & Speed \\
\hline Manual I & LB-26 & $6 \mathrm{~mm}$ & - & $\mathrm{D} 4316$ & E 6016 & $280 \sim 300 \mathrm{amp}$ & $24 \sim 27$ volt & $\begin{array}{c}230 \sim 250 \\
\mathrm{~mm} / \mathrm{min} .\end{array}$ \\
\hline Manual II & $\mathrm{B}-17$ & $6 \mathrm{~mm}$ & - & D 4301 & - & 270 -290 amp. & $30 \sim 33$ volt & $\begin{array}{c}320 \sim 350 \\
\mathrm{~mm} / \mathrm{min} .\end{array}$ \\
\hline Spring* & SW-27 & $5 \mathrm{~mm}$ & - & $\mathrm{D}$ & 27 & $230 \sim 250 \mathrm{amp}$. & $35 \sim 40$ volt & $\begin{array}{c}210 \sim 240 \\
\mathrm{~mm} / \mathrm{min} .\end{array}$ \\
\hline $\begin{array}{c}\text { Submerged } \\
\text { arc }\end{array}$ & $\begin{array}{c}\text { Lincoln } \\
\mathrm{L}-60\end{array}$ & $4.8 \mathrm{~mm}$ & $\begin{array}{l}\text { Lincoln- } \\
\text { weld } 780\end{array}$ & - & - & $700 \mathrm{amp}$. & 30 volt & $\begin{array}{l}460 \\
\quad \mathrm{~mm} / \mathrm{min} .\end{array}$ \\
\hline
\end{tabular}

Note : Spring weld is a kind of semi-automatic welding processes.

ね 8 種類であり, 各々につい て2Mil $(0.05 \mathrm{~mm}), 5 \mathrm{Mil}(0.13$ $\mathrm{mm}), 10 \mathrm{Mil}(0.25 \mathrm{~mm}), 20 \mathrm{Mil}$ $(0.51 \mathrm{~mm})$ の厚さ淦装した。 溎料の名称と成分を Table 1 に示す.

組立てを終った試験材飞効 して Table 2 に示す 4 程の 售接を塗料の種類招よび膜厚 の組会せにつき各1個づつ下 问姿勢で行い，各々につきそ の工作性を調查した.

\section{3 工業性試験結果}

工作性試験はアークのスタート，アークの安定性，ビー ドの外観灾よびX線透過試験以よりその判定を行った。

試験結果は Table 3 の通りである. 工作性試験結果よ り詳細な結覦を得るととは困難であるが大珐以下の如く教 えられる.

(1) 手熔接とスプリング塔接では, 塗膜厚さ $2 \mathrm{Mil}$ 程度
の場合は塗料の影響はほとえど見られない。

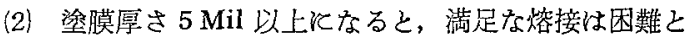
なる。

(3) 叙装面に対するサブマージドアーク熔接は塗膜の厚 さに無関係に施工困難である.

（4）滁料の種類が熔接工作性の良否に与光影響に関し ては, Wash Primer, Iron Oxide, Zinc Chromate 等 が比竷的良好と考学られる。

\section{4 龟裂 性 試 験}

工作性試験に招いて塗料の影響が殆んどみられなかった ものについて，塗膜が熔接部の拘束彗れに和上ほす影響を 調查するために，リ一八イ式拘束鼠裂性試験を行った. 試 鈋片以拘束度 80 あの（周縁飞切り込み型スリットのない もの）を使用した，試験に供した塗料の種類および熔接法 は Table 4 亿示す通りである。

\section{5 亀裂性試験結果}

叙装を行わない試験片で予借試験を行いFig. 2 の結果 が得られた．この結果より ManuaI I（低水素系手燃接） 
Table 3 Results of Weldability Test
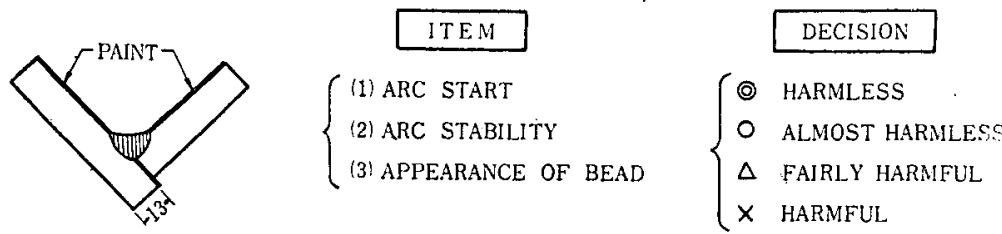

$X-$ RAY TEST

[---] NO BLOW HOLE

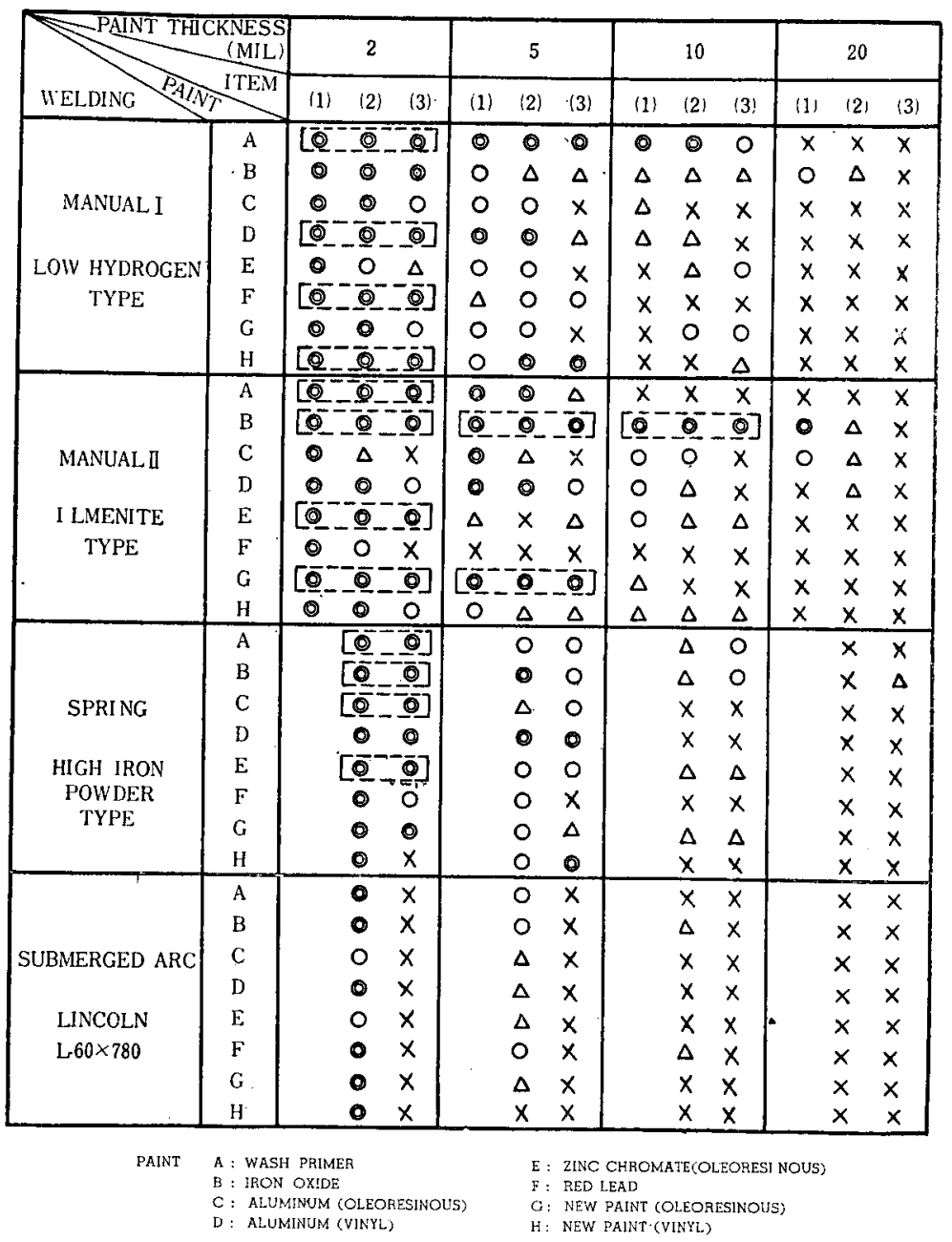

では $-20^{\circ} \mathrm{C}$, Manual II (イルミナ イト系手熔接) 垎よび Spring (高 鉄粉系スプリング焀接) では $70^{\circ} \mathrm{C}$ を試験温度とすることにした，試験 以同一条件决 3 個づつ行い角裂 長さは磁気検查法により測定した。 試験結果を Fig. 3 亿示す。な括と の試験江括いて怟水素系手撘接の 場合，涳膜のために裂感度が上る ばかりでなくビード表面に気孔が生 している. 試験温度が低いのて熍着 金属の泠却速度がかなり速く，ガス を充分放出できなかったととが主な 原因であると考学られる.イルミナ イト系手揢接括よび高鉄粉系手熔接 そ怙いても，塗膜注龟裂感度に概し て悪い影響を与えているが，その程 度は低水素系焀接棒之他の莶接棒の 間にみられるような顕著なむのでは ない，塗料の種類に関しては Wash Primer 特よび New Paint (Oleo.) が影響が少い結果が得られた。

\section{6 衝 擊 試 験}

塗料が溶着金属の切欠鞄性に和よ ぼす影響を調査するために，熔着金 属の標準 Vシャルピー獣競試験を行 った. 試験片は Fig. 4 亿示す試験 材より採取し，切欠は啙着金属中央 に板厚方にとった．試験材は開先面 括よび裹当金を塗装し，塗膜の影響 を熔着金属全体代括よぼすために 1 層を熔接する毎海装を行った。 試 験を行った塗料の種類招よび噡接法 は Table 5 亿示す通りである.

\section{II 衝撃試験結果}

燃接法と塗料の各組合せとつき，

Table 4 Paints and Welding Processes Applied in Lehigh Restraint Test

\begin{tabular}{|c|c|c|c|c|c|c|c|c|}
\hline \multirow{2}{*}{$\begin{array}{l}\text { Welding } \\
\text { process }\end{array}$} & \multicolumn{2}{|c|}{ Electrode } & \multicolumn{2}{|c|}{ Classification } & \multicolumn{3}{|c|}{ Welding condition } & \multirow{2}{*}{ Paint } \\
\hline & Name & Dia. & JIS & AWS & Current & Voltage & Speed & \\
\hline Manual I & LB 26 & $4 \mathrm{~mm}$ & D4316 & E6016 & $\begin{array}{r}160 \sim 170 \\
\text { amp. }\end{array}$ & $23 \sim 25$ volt & $\begin{array}{l}200 \sim 230 \\
\mathrm{~mm} / \mathrm{min} .\end{array}$ & \multirow{3}{*}{$\begin{array}{l}\text { No paint } \\
\text { Wash primer }(2 \text {-mil) } \\
\text { Iron oxide }(2-\text { mil }) \\
\text { Zinc chromate (oleo.) (2-mil) } \\
\text { New paint (oleo.) (2-mil) }\end{array}$} \\
\hline Manual II & B 17 & $4 \mathrm{~mm}$ & D 4301 & $\longrightarrow$ & $\begin{array}{r}160-165 \\
\text { amp. }\end{array}$ & $25 \sim 30$ volt & $\begin{array}{l}210 \sim 240 \\
\mathrm{~mm} / \mathrm{min} .\end{array}$ & \\
\hline Spring & SW 27 & $5 \mathrm{~mm}$ & D 4327 & E 6027 & $\begin{array}{r}\quad 210 \sim 215 \\
\text { amp. }\end{array}$ & $27 \sim 30$ volt & $\begin{array}{l}220 \sim 240 \\
\mathrm{~mm} / \mathrm{min} .\end{array}$ & \\
\hline
\end{tabular}




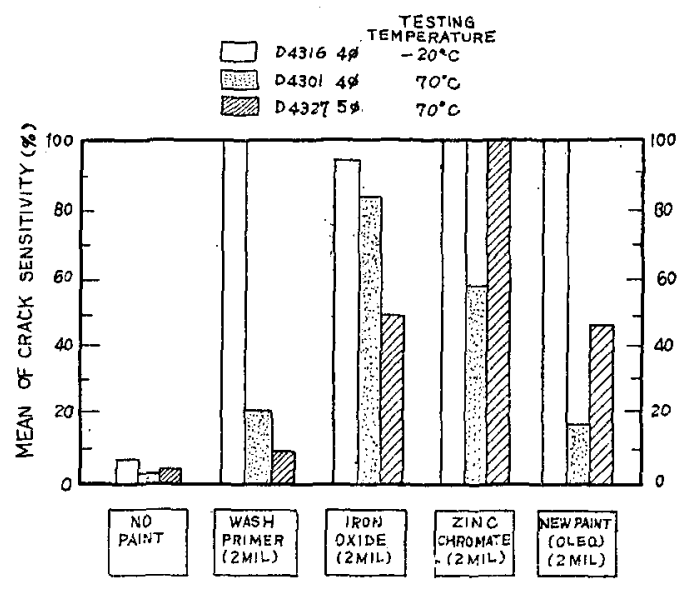

Fig: 3 Result of Lehigh restraint tests for painted specimens

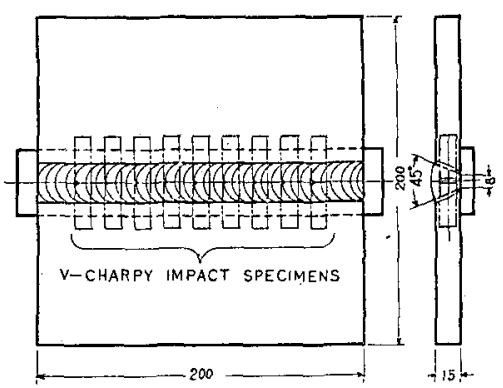

Fig. 4 Test specimen for V-Charpy impact test, whose groove faces, backing strip and deposited metal were recoated with 2 mils of various paints before welding next layer

$-20^{\circ} \mathrm{C}, 0^{\circ} \mathrm{C}$, $20^{\circ} \mathrm{C}$ の 3 温 度で衝撃試験 を行い Fig. 5 の結果得 た.な扮粱装 を行わないる の次て度 Fig. 6 より各 熔接棒の平均 吸収エネルギ 一を求め, 塗 膜を施した場 合の平均吸収 エネルギー淮移温度の基準とした. Fig. 7 に熔接法と塗料 の各組合せに対する平均吸収エネルギ一遙移温度と剪断破

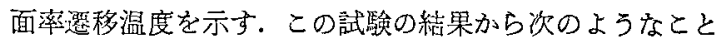
がいえる。

（1）低水素系乎熔接による熔着金属の衝撃值では塗料の 影響は汪とんど見出すととが出来ない。

(2)イルミナイト系手揢接では，Wash Primer を塗装 したものは漼膜のない場合に較べて衝整值が低く， Iron Oxide, Zinc Chromate を塗装したものは䘖
盤值が高 W.

(3) 高鉄粉 系スプリ ング熔接 では, Wash Pr imer を 滁装した ものが特 に衝拏值 加低い。

（4）低水素 系赀接棒 による暙 着金属は 一般に1 ルルナイ

卜系ある い惊鉄 粉采住 ベて高い 衝撃值を 有する。

(5) 以上の 結果加 みて,

Wash Pr. imer 鋈 装化やや 問題があ るが，そ の他の淕 装坆梁膜 厚さ2Mi1 程度では 熔盖金属 の衛軗值

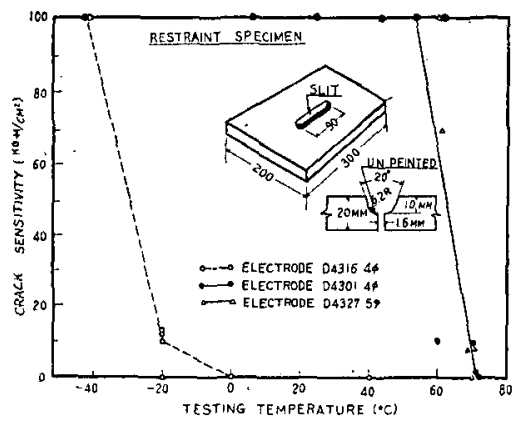

Fig. 2 Summaries of Lehigh restraint tests showing the effect of various electrodes
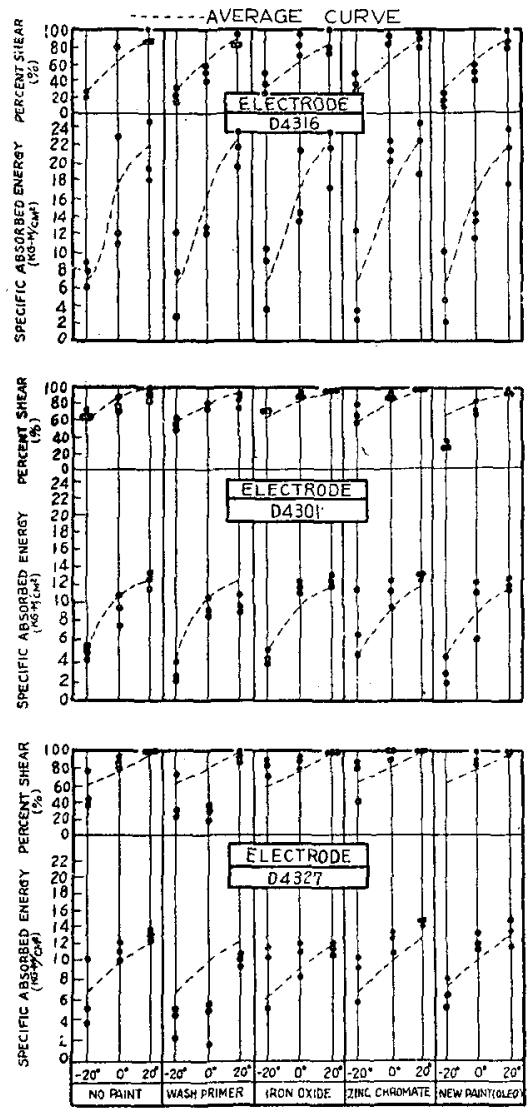

Fig. 5 Results of standard V-notch Charpy impact tests of weld metals, deposited in 2 mils painted groove joints

Table 5 Paints and Welding Processes Applied in V-Charpy Impact Test

\begin{tabular}{|c|c|c|c|c|c|c|c|c|}
\hline \multirow{2}{*}{$\begin{array}{l}\text { Welding } \\
\text { process }\end{array}$} & \multicolumn{2}{|c|}{ Electrode } & \multicolumn{2}{|c|}{ Classification } & \multicolumn{3}{|c|}{ Welding condition } & \multirow{2}{*}{ Paint } \\
\hline & Name & Dia. & JIS & AWS & Current & Voltage & Speed & \\
\hline Manual I & LB 26 & $6 \mathrm{~mm}$ & D 4316 & $\mathrm{E} 6016$ & $\begin{array}{r}260 \sim 320 \\
\text { amp. }\end{array}$ & $24-27$ volt & $\begin{array}{c}200 \sim 250 \\
\mathrm{~mm} / \mathrm{min} .\end{array}$ & \multirow{3}{*}{$\begin{array}{l}\text { No paint } \\
\text { Wash primer }(2-\text { mil }) \\
\text { Iron oxide }(2-\text { mil }) \\
\text { Zinc chromate (oleo.) }(2-\text { mil }) \\
\text { New paint (oleo.) }(2-\text { mil) }\end{array}$} \\
\hline Manual II & B 17 & $6 \mathrm{~mm}$ & D 4301 & - & $\begin{array}{c}250 \sim 300 \\
\text { amp. }\end{array}$ & $30 \sim 33$ volt & $\begin{array}{c}250 \sim 300 \\
\mathrm{~mm} / \mathrm{min} .\end{array}$ & \\
\hline Spring & SW 27 & $5 \mathrm{~mm}$ & D 4329 & E 6027 & $\begin{array}{c}230 \sim 250 \\
\text { amp. }\end{array}$ & $35-40$ volt & $\begin{array}{l}210 \sim 240 \\
\mathrm{~mm} / \mathrm{min} .\end{array}$ & \\
\hline
\end{tabular}




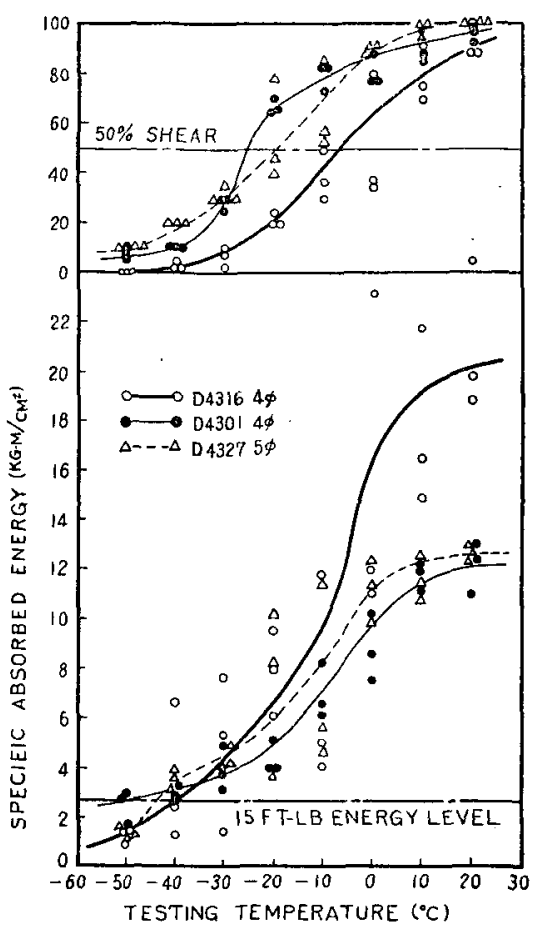

Fig. 6 Result of V-notch Charpy impact tests for unpainted specimens

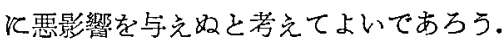

\section{8 分散分析法による衝撃試験結果の解析}

衝撃試験結果では，衝撃値のもつかなりのばらつきのた め飞，法っきりした結論を得ることは困難であった。ここ では衝撃試駼結果を統柿的飞扱うことによって検討を加え た．衛撃試駼結果の解析にはいるいるな方法が考兄られる が，熔接棒，試験温度，塗料を変動要因とすることによっ て3元配置法に上る分散分析を行うことができる．衛撃試 験は同一条件汇つき 3 個づつ行っているのでデータの絽返 しの数は 3 である.

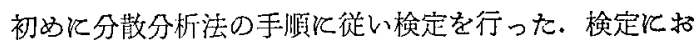
いては, 熔接棒, 試験温度, 潦料の各変動要因によるばら つきの程度，括よび各要因の組合せによるばらつきの程度

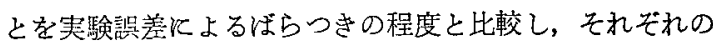
有意性を判定した。計算の過程けすべて省略し，分散分析 表から得られた結諭のみを述べれば次の通りである。

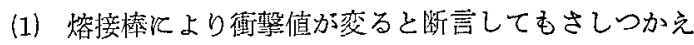
ない（佨険率 $1 \%$ 以下)

(2) 試験温度により衝撃值が変ると断言してもさしつか えない（危険率 $1 \%$ 以下）

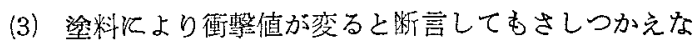
い.（危除率 $1 \%$ 以下)

(4) 熔接棒乙試 験温度の組合 せ浮よる交互 作用があると 断言してもさ しつかえない . (危除率 $1 \%$ 以下)

(5) 㸌接棒と塗 料の組合せ飞 よる交互作用 があるとはい えない（危険 率 $5 \%$ 以上）

(6) 試験温度之 塗料の組合せ 飞上る交互作 用があるとは い充ない。( 仜険率 $5 \%$ 以 上)

この研究のテ the effect of various paints on their notch toughness

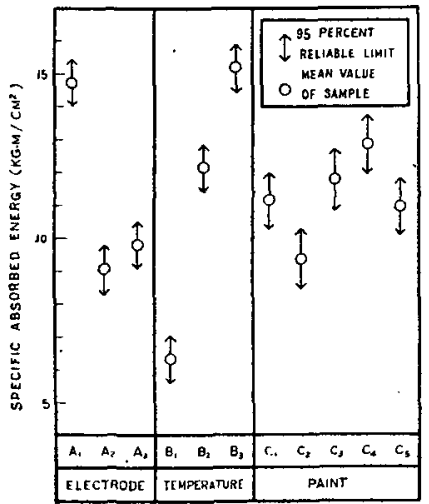

Electrode

$A_{1}$ : Low hydrogen type

$\left\{A_{2}:\right.$ Ilmenite type

$A_{3}:$ High iron powder type

Paint

$\left(C_{1}:\right.$ No paint

$\left\{C_{2}:\right.$ Wash primer (2 mils)

$C_{3}$ : Iron oxide $(2 \mathrm{mils})$

Temperature

$\left\{\begin{array}{rr}B_{1}: & -20^{\circ} \mathrm{C} \\ B_{2}: & 0^{\circ} \mathrm{C} \\ B_{3}: & 20^{\circ} \mathrm{C}\end{array}\right.$

$\mathrm{C}_{4}:$ Zinc chromate $(2 \mathrm{mils})$

$C_{5}$ : New paint (Oleo.) (2mils)

Fig. 8 Summaries of analysis of variance
ーマからみて垂要な 結論は(3)挌よび(5)で あるが，後者によ。 て判定すれば特定の 聺接棒と塗料の組合 せを考虑する必要は ないようである。

次有意と認めら れた熔接棒, 試験温 度, 渿料の各水準仡 ついて母平均存推定 乙 Fig. 8 の結果を 得た。平平均の推定 值は絶対值自体はあ まり意味のないもの であるが, 各要因が 衝整值に与える影響 の程度を知るめやす となるものである.

Fig. 8 の結果からみ る之, 低水菜系熔接 棒による熔着金属は イルミナイト系ある 
いは高鉄粉系飞較へてはるかに高い衛撃值を有している.

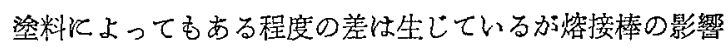
程湿著なものではない。

最後に Fig. 8 亿示した母平均の間汇差があるかどうか を検討してみた，検定結果のうち重要と思われるものを列 挙すれ活次の通りである。

(1) 低水索系熔接棒尬燃着金属はイルミナイト系あ るいは鉄粉系に較べて明らかて高い衝撃值を有してい を.

（2）イルミナイト系啙接棒による熔着金属と鉄粉系によ るむのとの閧には差があるとはいえない。

（3）Wash Primerを塗装した場合は，治膜のない場合 より季衝整值が明らか低い。

(4) Iron Oxide あるいは New Paint (Oleo.) を塗装し た場合は，㳂膜のない場合と差があるとはいえない。

(5) Zinc Chromateを叙装した場合は，塗膜のない場合 よりりも衛撃值が高い.

(2)(4)は有意差のないもの，(5)は有意なもの，(1)(3)は高 度有意なあのである。

\section{9 結 論}

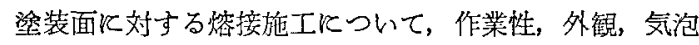
の有無を調查する工作性試験，龟裂感度を調查する䉓裂性 試験特よび接手性能を調查する衝撃試験を行った，各々の 試験の結果得られた結論は次の通りである.

（1）作業性，ビード外観呿よびX線透過試験により行っ た熔接工作性の観点から見れば低水素系手熔接，イル ミナイト系手燃接招よび高鉄粉系スプリング熔接では 塗莫厚さ $2 \mathrm{Mil}(0.05 \mathrm{~mm})$ 程度では塗料㹥あまり有害 な影響を招よぼさなかった。なかでも Wash Primer， Iron Oxide, Zinc Chromate, New Paint (Oleo.) な どは仼とんど影響がなかった。

塗膜厚さが $5 \mathrm{Mil}(0.13 \mathrm{~mm})$ 以上になると，塗料の
種類，签接法のいかんに拘わらず満足な熔接拖工は困 難となる。

サブマージドアーク燃接て招いては筀料は塗膜厚さ 飞無関係江有害である。

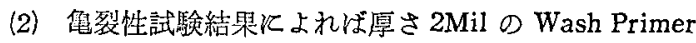
と New Paint (Oleo.) は龟裂感度にほとえど影響を与. えない. Iron Oxide と Zinc Chromate は龟裂感度を 多少上昇させる.

（3）厚さ 2Mil の Wash Primer を塗装した場合, 熔着 金属の衝椠檤は明らか低下して括りZinc Chromate を笁装した場合は上っているが，その理由は明確でな い,

な特 Iron Oxide 呿よび New Paint (Oleo.) を塗 䔩した場合は衝揧値に洼とえど影響を与えない。

(4) 各々の試験結果を総合すると，厚さ 2 Mil 以下の Wash Primer, Iron Oxide, Zinc Chromate, New Paint (Oleo.) 等の㳂膜は, 試験汇より程度の造い山あるが, 接手の熔接性に致命的な影響を与兄ることはないよう に思われる.

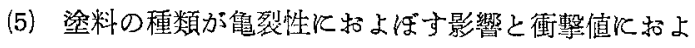
ぼす影響が必ずしも一致せずむしる相反する性質を示 していることについては今後な赫研究の必要が認めら れる.

後 記

この実験を行うにあたり日本油脂佐藤信夫研究課長に御 拹力を頂いたことを追記し謝意を表する次第である.

$$
\text { 文献 }
$$

1) Effect of Zinc Chromate Paint on Welding, C.T. Gayley. The Welding Journal 21 (9) Research Suppl. 653-s to 663-s (1942)

2) Studies on the Effects of Red Lead Paints on the Quality of Metal-Arc Welds in Structural Steel, R.W. Bennett, R.D. Williams and C.B. Voldrich. 